\title{
Simulating the Influences of the Blade Number and the Rotation on the Annual Energy Performance of the Wind Machine
}

\author{
Aditya Rachman \\ Department of Mechanical Engineering Haluoleo University \\ Kampus Hijau Bumi Tridarma Andounohu, Southeast Sulawesi Indonesia \\ ${ }^{+}$Corresponding author email: aditya_rchmn@yahoo.com
}

\begin{abstract}
The wind machine performance and the wind frequency characteristic at which the machine located can considerably influence the annual energy production of the technology. The design parameters of blade number and rotational operation have been proved to have an effect on the wind machine performance in many studies. This paper explores the annual energy production of a wind machine on the variation of the blade number and the rotational operation with consideration of the wind frequency characteristic condition. The methodology of generating this study is a simulation using the aerodynamic mathematical model of the Blade Element Momentum and the Weibull model. The results of this study indicate that at low rotational operation the annual energy production for the high bladed turbine is higher than that with lower number for all wind characteristic conditions investigated, while, at the high rotational operation, the low bladed turbine has better annual energy production.
\end{abstract}

Keywords: blade number, rotational operation, annual energy, wind turbine, wind occurrence, simulation

\section{Introduction}

The requirement on the understanding of the economical feasibility is important as it possibly delivers figures on whether a proposed technology will have economic senses or not when it is put into application. To assess the economical attractiveness on the application of the wind technology, one of important activities is to determine the annual energy production.

A factor that may influence the annual energy production of the machine is the performance. The higher machine performance, the higher annual energy possibly obtained is. The machine performance can be determined by the technology design. One of the design parameters of the wind technology is the blade number. It is apparently reasonable that the more blades mean the more performance derived. But the modern horizontal wind turbines generally have only a small number of blades. It is believed that the increasing on the blade number of the wind turbine can increase the performance. But, putting too many blades may result in an aerodynamic complication, reducing the performance [1]. The turbine with very high blade number may cause the reduction on the performance driven by stall looses [2]. Another factor that can influence the performance is the rotational operation of the wind turbine. Several works [3-8] show the role of the rotational operation on the wind machine performance. These works indicate that, under the same velocity condition, the turbines with high blade number have higher performance at low rotational operation, while the turbines with lower blade number perform better at higher rotation operation. 


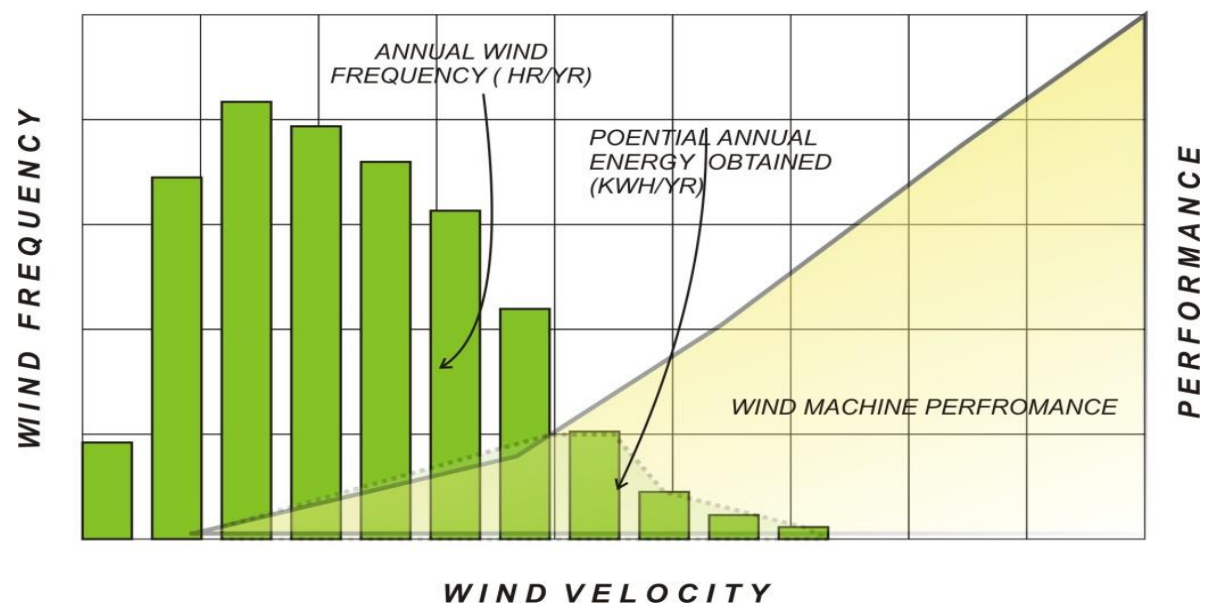

\section{Figure 1. The Influences of the Wind Machine Performance and the Wind Frequency on the Annual Energy Generation}

Another factor that may also influence the annual power production is the wind frequency characteristic condition in the location where the machine operates. Even one can design a wind machine with a promising high performance; the characteristic of the low and infrequent wind condition in the location where the machine is located possibly causes less energy production, making the technology application uneconomically attractive.

The inclusion of the effect of the wind frequency characteristic in many wind studies which relate to the design parameters, such as the blade number, seems to be less presented. Many studies [3-9] seem to focus on the effect of the blade number on the performance of the wind machines relating to only the parameters of velocity and rotation. This information seems to be less representative as the source to assess the annual energy production, one of the essential parameters in determining the economical attractiveness of the wind machine application. The aim of this study is to investigate the annual energy production of a wind machine in the variation of the turbine design parameters of blade number and rotational operation with inclusion on the influence of the wind frequency characteristic.

\section{Methodology}

The methodology of generating this study is a simulation using the Blade Element Momentum (BEM) model and the Weibull model. Initially, it determines the characteristic of the wind machine performance in the variation of the blade number and the rotational operation derived from a parametric study using the Momentum model. Then, the result is combined with the characteristic of the annual wind frequency derived from the Weibull model to obtain the annual energy generation.

\subsection{The Blade Element Momentum (BEM) Model}

The BEM model can be utilized in designing the blade of turbine and in evaluating the wind turbine performance [9]. Using this model, it is possible to evaluate the forces acting on the blades, and the torque and the power at a rotor shaft with a wide range of wind velocities. In the model, the power of the turbine, $\mathrm{P}_{\mathrm{V}}($ watt $(\mathrm{W}))$ at a wind velocity $(\mathrm{V}(\mathrm{m} / \mathrm{s}))$ is expressed $[1,2]$ as

$$
\mathrm{P}_{\mathrm{V}}=\eta \int_{\mathrm{rh}}^{\mathrm{R}} \frac{4 \mathrm{~B} \Omega \rho \mathrm{V}^{2} 1 \mathrm{r} \Pi}{15(\mathrm{~K}+4)^{2}(\sin (\alpha+\theta))^{2}}\left(\mathrm{C}_{\mathrm{L}} \sin (\alpha+\theta)-\mathrm{C}_{\mathrm{D}} \cos (\alpha+\theta)\right) \mathrm{dr}
$$


Where, B is the blade number, $\rho$ is the specific mass of air $\left(\mathrm{kg} / \mathrm{m}^{3}\right), 1$ is the cord length of the cross section (aerofoil) of the turbine blade $(\mathrm{m}), \mathrm{K}$ is the dimensionless parameter of loading coefficient, $\mathrm{R}$ is the turbine radius $(\mathrm{m})$, rh is the turbine hub radius $(\mathrm{m}), \Omega$ is the rotation of the turbine (RPM), $\theta$ is the blade angle $\left({ }^{\circ}\right), \alpha$ is the attack angle $\left({ }^{\circ}\right), \mathrm{r}$ is the elemental blade radius $(\mathrm{m}), \mathrm{C}_{\mathrm{L}}$ and $\mathrm{C}_{\mathrm{D}}$ is the lift and drag coefficients of the cross section (aerofoil) of the turbine blade and $\eta$ is the generator and transmission efficiency.

\subsection{Weibull Model}

Wind speed is a random variable and the variation of the wind speed over a period of time can be represented by probability density functions such as gamma, lognormal, three parameter beta, Rayleigh and Weibull distributions [10]. In recent years Weibull distribution has been one of the most commonly used, accepted and recommended distributions to determine wind energy potential and has been employed as a reference distribution for some commercial wind energy softwares [11]. Many studies [12-17] have utilized the Weibull model in analyzing wind energy potential and in finding out the wind energy density and other wind characteristics in various locations in the globe, such as India, Algeria, Malaysia, Jordan, Indonesia and Iran. The annual wind frequency, $f_{\mathrm{v}}(\mathrm{h} / \mathrm{yr})$ at a wind velocity (V) derived from the Weibull distribution model can be expressed as

$$
\mathrm{f}_{\mathrm{v}}=(8760) \frac{\mathrm{k}}{\mathrm{C}}\left(\frac{\mathrm{V}}{\mathrm{c}}\right)^{\mathrm{k}-1} \exp \left[-\left(\frac{\mathrm{V}}{\mathrm{c}}\right)^{\mathrm{k}}\right]
$$

where, $\mathrm{c}$ is the Weibull scale parameter and $\mathrm{k}$ is the Weibull shape parameter.

\subsection{Annual Energy Production}

The annual energy production of a wind machine for a certain wind velocity with its annual frequency, $\mathrm{W}_{\mathrm{V}}(\mathrm{KWh} / \mathrm{yr})$, can be formulated by

$\mathrm{W}_{\mathrm{V}}=10^{-3} \mathrm{P}_{\mathrm{V}} \mathrm{f}_{\mathrm{v}}$

Thus, the total annual energy output, $\mathrm{W}_{\mathrm{VT}}(\mathrm{KWh} / \mathrm{yr})$ can be formulated by

$$
\mathrm{W}_{\mathrm{VT}}=\int_{0}^{\mathrm{Vmax}} \mathrm{W}_{\mathrm{V}} \mathrm{dV}
$$

where $V_{\max }(\mathrm{m} / \mathrm{s})$ is a velocity at which, in the wind frequency characteristic modeled as the Weibull, the velocities beyond it $\left(\mathrm{V}_{\max }\right)$ have almost a zero frequency.

\subsection{Data of Investigation}

In inputting the data into the BEM model, the turbine radius $(\mathrm{R})$ is set to be $2.7 \mathrm{~m}$ and the hub radius (rh) is set to be $0.2 \mathrm{~m}$. The cord length (1) is set to be $0.3 \mathrm{~m}-0.2$ $\mathrm{m}$ (from hub to tip). The type of the aerofoil is NACA 2451 in which the data of $\mathrm{C}_{\mathrm{L}}$ and $C_{D}$ for this aerofoil is derived from a study in (Hughes, 2009). The blade angle $(\theta)$ is set to be $4^{\circ}$. The blade number (B) is varied by 3 and 9 , and the rotation of the turbine $(\Omega)$ is varied by 100 RPM and 200 RPM. The efficiency of transmission and generator $(\eta)$ is assumed to be 0.5 .

In the Weibull model, it employs the data of the annual wind frequency modeled as Weibull distribution in Makassar Indonesia [in 15] and Abaqa Jordan [in 12]. The results for the modeled wind frequency are the annual wind frequency characteristic modeled as Weibull function at the scale factor (c) of 2.52 and shape factor (k) of 1.52 , and at the scale factor (c) of 5.37 and the shape factor $(\mathrm{k})$ of 2.26 , respectively. The maximum velocity $\left(\mathrm{V}_{\max }\right)$ in present study is $16 \mathrm{~m} / \mathrm{s}$. 


\section{Results and Discussion}

\subsection{Annual Energy Production at $\mathrm{c}=\mathbf{2 . 5 2}$ and $\mathrm{k}=\mathbf{1 . 5 2}$}

The results in this wind frequency condition show that the turbine with nine blades has better annual energy production than that of the three-bladed turbine at 100 RPM, while at 200 RPM, the three-bladed turbine has better annual power production than that of the nine-bladed turbine (see Figure $2 \& 3$ ). At this wind condition, the occurrence of the wind speed above $3 \mathrm{~m} / \mathrm{s}$ is lower than that of the wind speed of $2 \mathrm{~m} / \mathrm{s}$ to $3 \mathrm{~m} / \mathrm{s}$ (see Figure $2 \& 3$ ).

At the rotation of $100 \mathrm{RPM}$, the power of the turbine with three blades is better than that of the turbine with nine blades on the velocity range of $2 \mathrm{~m} / \mathrm{s}$ to $6 \mathrm{~m} / \mathrm{s}$, while at the velocities above $6 \mathrm{~m} / \mathrm{s}$, the turbine with nine blades performs better than the turbine with three blades. It seems that the condition of the higher power for the velocity range of $2 \mathrm{~m} / \mathrm{s}$ to $6 \mathrm{~m} / \mathrm{s}$ where the frequency on this velocity range is high, brings the higher annual energy output for the three-bladed turbine than that of the nine-bladed turbine. However, the result shows reversing; the nine-bladed turbine obtains higher annual energy production than that of the turbine with three blades. One of the reasons is that the power generated in this velocity range $(2 \mathrm{~m} / \mathrm{s}$ to $6 \mathrm{~m} / \mathrm{s})$ would be low as the power is the function of the cubic velocity. The nine-bladed turbine which has the higher performance at the velocities above $6 \mathrm{~m} / \mathrm{s}$, can obtain higher energy than that of the lower-bladed turbine as the power generated from the velocities above $6 \mathrm{~m} / \mathrm{s}$ is higher than those of $2 \mathrm{~m} / \mathrm{s}$ to $6 \mathrm{~m} / \mathrm{s}$ (even the occurrence on the velocities above $6 \mathrm{~m} / \mathrm{s}$ is lower than that of the velocities of $2 \mathrm{~m} / \mathrm{s}$ to $6 \mathrm{~m} / \mathrm{s}$ ) (see Figure 2).
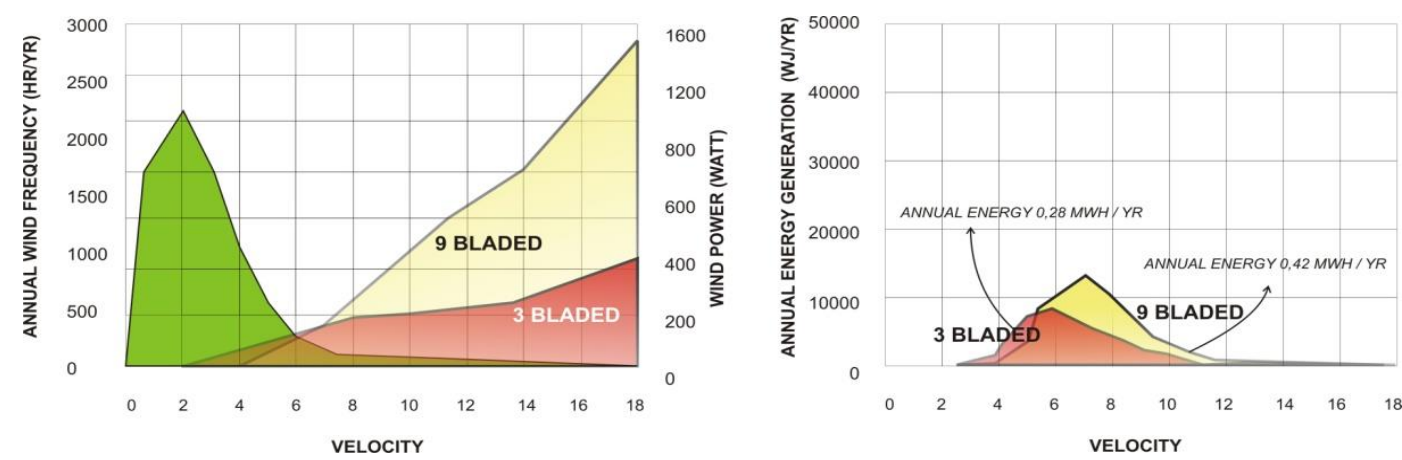

Figure 2. The Annual Energy Production at 100 RPM (c= 2.52 and $k=$ 1.52)
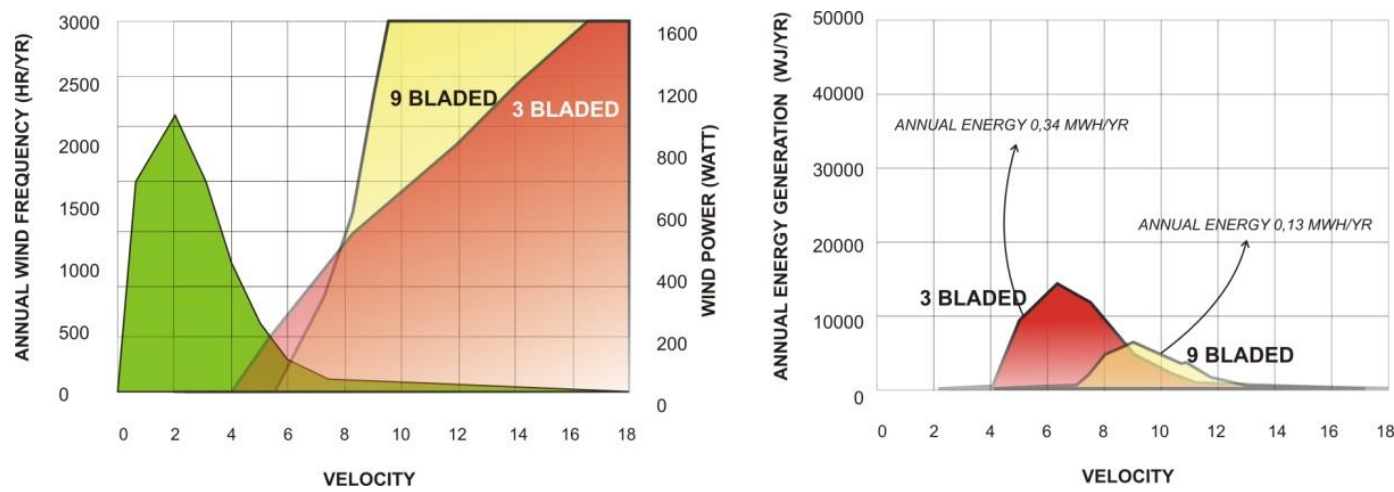

Figure 3. The Annual Energy Production at 200 RPM (c=2.52 and k= 1.52) 
At 200 RPM, the performance of the turbine with three blades is higher than that of the turbine with nine blades for the velocity range of $4 \mathrm{~m} / \mathrm{s}$ to $7.5 \mathrm{~m} / \mathrm{s}$, while for the velocities above $7.5 \mathrm{~m} / \mathrm{s}$, the nine-bladed turbine performs better. As the annual wind frequency for the velocity range of $4 \mathrm{~m} / \mathrm{s}$ to $7.5 \mathrm{~m} / \mathrm{s}$ is considerably higher than that of the velocity above $7.5 \mathrm{~m} / \mathrm{s}$ (see Figure 3), the turbine with three blades benefits in obtaining the higher annual energy production than that of the turbine with nine blades. This can be the reason for the higher annual energy production of the turbine with three blades than that of the turbine with nine blades at $200 \mathrm{RPM}$ at corresponding wind condition.

\subsection{Annual Energy Production at $c=5.37$ and $k=2.26$}

In this wind frequency condition, the turbine with three blades has lower annual energy production than that of the nine-bladed turbine at 100 RPM, while at 200 RPM the three-bladed turbine has better annual energy production than that of the high bladed turbine (see Figure 5\&6).

At corresponding wind frequency condition, the occurrence of the wind speed below $3 \mathrm{~m} / \mathrm{s}$ is relatively lower than those above $3 \mathrm{~m} / \mathrm{s}$. As at $100 \mathrm{RPM}$, the power of the turbine with nine blades is better than that of the turbine with three blades at the velocity region above $6 \mathrm{~m} / \mathrm{s}$, where the annual occurrence for corresponding wind region is high, it causes the higher annual energy output than that of the turbine with three blades (see Figure 5). At 200 RPM, the condition of the higher performance at the velocity region of $4 \mathrm{~m} / \mathrm{s}$ to $7 \mathrm{~m} / \mathrm{s}$ where the annual frequency for corresponding velocity region is high results in the higher annual energy output for the turbine with three blades than that of the nine-bladed turbine (see Figure 6).
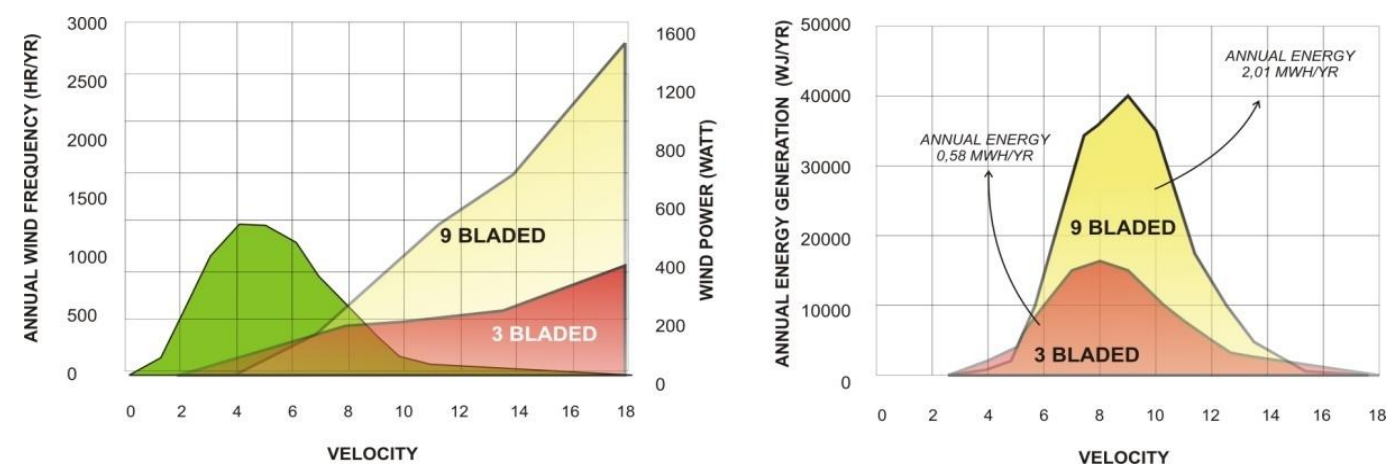

Figure 4. The Annual Energy Production at 100 RPM (c= 5,37 and $k=$ 2,26)
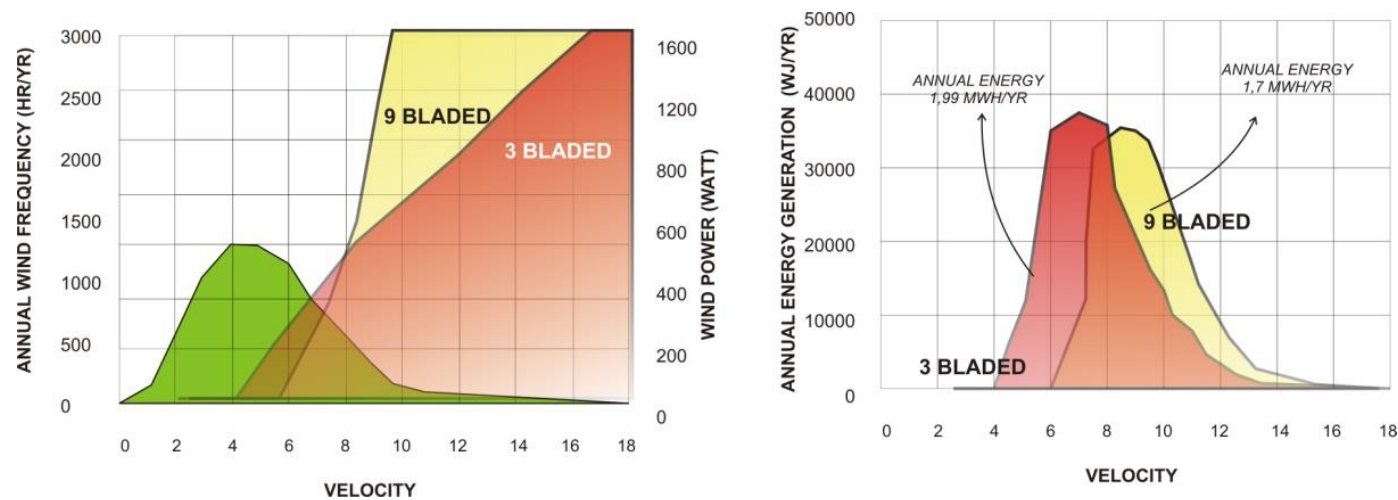

Figure 5. The Annual Energy Production at 200 RPM ( $c=5,37$ and $k=$ 2,26) 
The results in the annual energy productions for the different blade number and rotation in the two different wind frequency characteristics seem to have a similar pattern. The similarity can be seen from the high annual energy production for the high bladed turbine with low rotational operation and the high annual energy production for the low bladed turbine with high rotational operation. However, in both wind frequency conditions, the amount of the annual energy production is different. Turbines operating at the wind occurrence condition of $\mathrm{c}$ of 5.37 and $\mathrm{k}$ of 2.26 have higher annual energy production than that of the turbines operating at $\mathrm{c}$ of 2.52 and $\mathrm{k}$ of 1.52. This is because that the existence of the high wind speeds in the wind condition of $\mathrm{c}$ of 5.37 and $\mathrm{k}$ of 2.26 is higher than that of the wind condition with $\mathrm{c}$ of 2.52 and $\mathrm{k}$ of 1.52 .

\section{Conclusion}

This study has simulated the annual energy production on the wind machine in the variation of the blade number and the rotational operation in the different wind occurrence condition. The following are some conclusions that can be drawn.

For both wind frequency conditions, there is a similar tendency of the high annual energy production for the high bladed turbine with low rotational operation and the high annual energy production for the low bladed turbine with high rotational operation. A certain configuration of blade number and rotation can create a specific performance characteristic of the wind machine. In this characteristic, it does not always guarantee for the high machine performance in all velocity range. The population of the annual wind occurrence may accumulate at a certain range of velocity, while in other range it may be rare, vice versa. A wind machine with its specific performance characteristic may derive an advantage of the high annual energy production when both the performance at a certain range of velocities and the annual wind frequency for corresponding speed range are high. In contrary, even the performance is high for a certain range of velocities; the low population on the annual wind frequency for corresponding range may disadvantage the machine in obtaining the high annual energy production. In other case, it is possible for a turbine with high performance at a certain velocity range where the population of annual wind frequency is high to obtain low annual energy production as the velocities in the range have a low speed characteristic.

\section{References}

[1] E. Hau, "Wind Turbines Fundamentals Technologies Application Economics", Springer Verlag, Berlin, (2000).

[2] T. Burton, D. Sharpe, N. Jenkins and E. Bossanyi, "Wind Energy Handbook", John Wiley \& Sons Ltd, England, (2001).

[3] S. Atmadi and A. J. Fitroh, "Analisis dan Optimasi Sudu SKEA 5 KW untuk Pemompaan", Journal of Teknologi Dirgantara, vol. 8, (2010), pp. 108-115.

[4] D. Y. C. Leung, Y. Deng and M. K. H. Leung, "Design Optimization of a Cost-Effective Micro Wind Turbine", Proceedings of the World Congress on Engineering 2010. (2010), Vol 2 WCE London, U.K. Available online: www.iaeng.org/publication/WCE2010/ WCE2010_pp988993.pdf.

[5] Y. Nishizawa, "An Experimental Study of the Shapes of Rotor for Horizontal-Axis Small Wind Turbines, Wind Turbines", Ibrahim Al-Bahadly (Ed.) InTech, Available online: http://www.intechopen.com/articles/show/title/an-experimental-study-of-the-shapes-of-rotorfor-horizontal-axis-small-wind-turbines, (2011).

[6] A. Rachman, "Parametric Study of a Horizontal Axis Ducted Wind Turbine, Master Engineering Thesis", University of Wollongong, Faculty of Engineering, NSW Australia, (2010).

[7] J. Swanson and K. Visser, "Improving the Efficiency of Small Wind Turbines by Optimizing Blade Number and Solidity", Available online: www.clarkson.edu/reu/archives/2002/abstracts/Swanson.pdf, (2002).

[8] S. H. Wang and C. H. Cheng, "Blade number effect for a ducted wind turbine", Journal Mechanical Science Technology, vol. 22, (2008), pp. 1984-1992. 
[9] R .Lanzafame and M. Messina, "Horizontal axis wind turbine working at maximum power coefficient continuously”, Journal Renewable Energy, vol. 35, (2010), pp. 301-306.

[10] A. Ucar and F. Balo, "Assessment of wind power potential for turbine installation in coastal areas of Turkey", Journal Renewable and Sustainable Energy Reviews, vol. 14, (2010), pp. 1901-1912.

[11] A. Seyit and A. Dinler, "A new method to estimate Weibull parameters for wind energy applications", Journal Energy Conversion and Management, vol. 50, (2009), pp. 1761-1766.

[12] M. A. Alghoul, M. Y. Sulaiman, B. Z. Azmi and M. A. Wahab, "Wind Energy Potential of Jordan", International Energy Journal, vol. 8, (2007), pp. 71-78.

[13] A. Celik and A. Naci, "Energy output estimation for small-scale wind power generators using Weibull-representative wind data", Journal of Wind Engineering \& Industrial Aerodynamics, vol. 91, no. 5, (2003), pp. 693-707.

[14] J. G. M. Herbert, S. Iniyan, E. Sreevalsanc and S. Rajapandiand, "A review of wind energy technologies", Journal Renewable and Sustainable Energy Reviews, vol. 11, (2007), pp. 11171145 .

[15] S. Himran, "Potensi Energi Angin (Studi Kasus untuk Wilayah Kodya Makassar dan Sekitarnya)", Journal Forum Teknik, vol. 26, no. 1, (2002).

[16] M. R. Islam MR, S. Saidur and N. A. Rahim, "Assessment of wind energy potentiality at Kudat and Labuan", Malaysia using Weibull distribution function, Journal Energy, vol. 36, no. 2, (2011), pp. 985-992.

[17] A. S. Shata and R. Hanitsch, "The potential of electricity generation on the east coast of Red Sea in Egypt", Journal Renewable Energy, vol. 31, (2006), pp. 1597-625.

\section{Author}

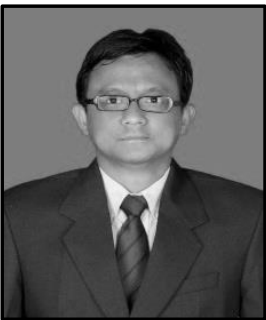

Aditya Rachman, born in Surakarta Indonesia 11st April 1979. He received his Bachelor of Mechanical Engineering degree from Gadjah Mada University Indonesia in 2003 and his Master Engineering degree from the Engineering Faculty of Wollongong University Australia in 2010.

$\mathrm{He}$ is a lecturer in Mechanical Engineering Department of Halu Oleo University Indonesia. $\mathrm{He}$ is interested in the research relating to the development of small wind and river current energy technologies. $\mathrm{He}$ has published some papers in some national and international conferences and international journals. 
International Journal of Energy, Information and Communications Vol.5, Issue 6 (2014) 